Platskamp, specialnummer av

Arkiv. Tidskrift för sambällsanalys, nr 9 (2018)

\title{
Aktivism som platskamp. Självpositionering och medborgarskapande inom den svenska förortsrörelsen
}

\author{
René León Rosales \& Aleksandra Ålund
}

SAMMANDRAG: I sin artikel undersöker René León Rosales och Aleksandra Ålund de processer som villkorar och möjliggör framväxten av en subjektsposition som aktivist bland ungdomar tillhörande en postmigrant-generation inom den svenska urbana rättviserörelsen som kallats den nya "förortsrörelsen". Artikeln utgör en fallstudie av Megafonen, en ungdomsledd organisation grundad i Husby som var central för framväxten av förortsrörelsen. I fokus står den unga aktivisten "Jasmines” livsberättelse. Empiriskt baseras artikeln på material insamlat sedan 2014 genom deltagande observation, videoinspelningar, intervjuer samt texter, video och bilder hämtade från internet och pressen. Författarna undersöker relationen mellan individuella och kollektiva lärandeprocesser samt transcenderande identitetsprocesser förankrade i rörelsens "platskamp" i rasifierade urbana landskap. Genom begreppet "aktivistiskt medborgarskap" belyser artikeln förortsrörelsens platskamp som ett samtida uttryck för medborgarskapande genom vilket unga vuxna politiserar sina erfarenheter av marginalisering och diskriminering och kräver sin rättmätiga plats i samhället.

NYCKELORD: aktivism; aktivistmedborgare; urbana rättviserörelser; Husby; Megafonen; rasifiering; postmigrant-ungdom; platskamp; segregation.

PUBLICERINGSHISTORIK: Originalpublicering.

RENÉ LEÓN ROSALES är etnolog och forskningsledare vid Mångkulturellt centrum. E-POSTADRESS: rene.leon.rosales@mkcentrum.se

ALEKSANDRA ÅLUND är professor vid REMESO vid Linköpings universitet. E-POSTADRESs: aleksandra.alund@liu.se

FÖRSLAG PÅ KÄLLANGIVELSE:

León Rosales, René \& Aleksandra Ålund (20I8) "Aktivism som platskamp. Självpositionering och medborgarskapande inom den svenska förortsrörelsen", i Platskamp, specialnummer av Arkiv. Tidskrift för sambällsanalys, nr 9, s. 53-76.

DOI: https://doi.org/10.13068/2000-6217.9.2

(C) Författarna/Arkiv förlag \& tidskrift 2018 (publicerad 28 maj 20I8)

Artikeln distribueras enligt en upphovsrättslicens från Creative Commons: Erkännande-Ickekommersiell-IngaBearbetningar 3.0 Unported, som medger fri ickekommersiell användning och spridning i oförändrat skick så länge källan anges. 
Arkiv. Tidskrift för samhällsanalys är en sakkunniggranskad vetenskaplig tidskrift för samhällsvetenskap och historia. Samtliga artiklar publiceras fritt tillgängliga på:

$$
\text { www.tidskriftenarkiv.se }
$$

Beständig länk, DOI: https://doi.org/IO.I3068/2000-62I7

Den här artikeln finns tillgänglig i följande format:

PDF: via beständig länk, DoI: https://doi.org/IO.I3068/2000-6217.9.2

TRYCK: ingår i bokutgåva av numret, ISBN: 978 9I 79243159

Grafisk utformning och sidnumrering är identisk i pdf och tryck.

Samtliga artiklar i nr 9 (2018), Platskamp, nås via beständig länk, DOI: https://doi.org/I0.I3068/2000-6217.9

Redaktion för nUmret: Magnus Dahlstedt, Lisa Kings \& Nazem Tahvilzadeh

Arkiv. Tidskrift för sambällsanalys

ISSN: 2000-62I7 (för elektronisk resurs)

ISSN: 2000-6225 (för tryckta nummer)

ges ut av

Stiftelsen Arkiv för främjande och spridning av samhällsvetenskaplig och historisk forskning

genom

Arkiv förlag \& tidskrift

Box 1559

SE-22I OI Lund

BESÖK: L Gråbrödersg 3 c, ipg

TEL: 046-I3 3920

ARKIV FÖRLAG: arkiv@arkiv.nu·www.arkiv.nu

TIDSKRIFTEN ARKIV: red@tidskriftenarkiv.se.www.tidskriftenarkiv.se

ANSVARIg UTGIVARE \& CHEFREDAKTÖR: Sven Hort

AdMinistrativ Redaktör: David Lindberg

Redaktörer: Paavo Bergman, Per Dannefjord, Lisa Kings,

Zhanna Kravchenko, Anna-Maria Sarstrand Marekovic 


\section{Aktivism som platskamp. Självpositionering och medborgarskapande inom den svenska förortsrörelsen}

\section{RENÉ LEÓN ROSALES \& ALEKSANDRA ÅLUND}

\section{Introduktion}

Ungdomar och unga vuxna från socioekonomiskt utsatta storstadsområden i Sverige har under de senaste åren trätt fram som viktiga aktörer i motståndet mot en nyliberal utveckling i det svenska samhället. En ökande ekonomisk ojämlikhet med överlappande etnisk och ekonomisk segregation i boende, utbildning och på arbetsmarknaden har särskilt drabbat områden med höga andelar människor ur så kallade synliga minoriteter, det vill säga med bakgrund i Asien, Afrika och Latinamerika (Socialstyrelsen 20IO; Schierup \& Ålund 20II; Edling 20I5). Genom processer av kulturell och territoriell stigmatisering skapas dessa områden som "förorten", vilken symboliskt främst kopplas ihop med sociala problem och kriminalitet (Sernhede 2002; Wacquant 2008).

Social ojämlikhet och kulturell stigmatisering har fungerat som en grogrund för både motstånd och identitetsskapande bland ungdomar och unga vuxna från dessa områden. De har startat en rad nya organisationer och nätverk som försöker motverka en politiskt iscensatt nedmontering av välfärdstjänster och därmed en nyliberal samhällsutveckling i Sverige (Harvey 2005; Schierup \& Ålund 20II; León Rosales \& Ålund 20I7). Aktivister i organisationer som Megafonen i Stockholm, eller som Pantrarna för upprustning av förorten i Göteborg, Rörelsen Gatans röst och ansikte i Malmö, för att nämna några exempel, bedriver 
folkbildning i sina områden för att höja kunskapen om de processer som leder till ökad ojämlikhet och kulturell stigmatisering. Dessa aktörer utgör tillsammans en ny social rörelse i Sverige, en urban rättviserörelse som i den offentliga debatten kommit att kallas den nya "förortsrörelsen" (Sernhede \& Söderman 2013; Tahvilzadeh 20I3). Den aktivism som kommer till uttryck inom denna rörelse kan på ett övergripande plan sägas vara uttryck för en pågående platskamp, det vill säga en kamp för att förändra den egna rumsliga verkligheten och de maktförhållanden som orsakar förortens utsatthet. Genom platskampen skapas nya gemenskaper och identiteter. Förortsrörelsens platskamp har därmed en performativ dimension som med sociologen Naomi Abrahams ord kan beskrivas som en produktion av nya gemenskaper och identiteter "som i maktrelationernas kamp är utrustade med ett syfte och en handlingsplan” (Abrahams 1996, s. 769, vår översättning).

En av de organisationer som var centrala för framväxten av förortsrörelsen är Megafonen, en ungdomsorganisation som grundades i Husby 2008. Under några år blev den en viktig aktör i den samhälleliga debatten om ojämlikhet i relation till socioekonomiskt utsatta stadsdelar och dess invånare. Megafonen kommer att vara i fokus för vår artikel, vars syfte är att undersöka hur identitetsskapande processer kopplade till motstånd mot en ojämlik samhällsordning artikuleras i den aktivism som Megafonen är ett uttryck för. I vår undersökning kommer vi att sammanlänka Megafonens organisationshistoria med en livsberättelse från en ung kvinna, Jasmine, som var aktiv i organisationen under flera år.

De forskningsfrågor som vägleder vår analys är följande:

- Vad kännetecknar aktivismen som kommer till utryck i organisationen Megafonen?

- Hur uttrycks sammankopplingen mellan objektiva och subjektiva förhållanden i Jasmines självpositionering som aktivist i hennes livsberättelse?

- Vilka identitetsprocesser möjliggörs av Jasmines identifikation med Megafonen?

Med utgångspunkt i dessa frågor vill vi synliggöra hur den aktivism som uttrycks i såväl Jasmines berättelse som genom Megafonens his- 
toria kan förstås i termer av transcenderande identitetsskapande. Detta begrepp beskriver hur en individ kommer att inta en position som aktivist genom att utveckla ett kritiskt perspektiv på den rasifierande stigmatiseringen av förorten och bristerna i de demokratiska processerna när det gäller medborgerligt deltagande. Dessa insikter blir vägledande för såväl individuella som kollektiva handlingar och bär med sig möjligheten att överskrida tillskrivna/underordnande identiteter. I förlängningen leder denna utvecklingsprocess till möjligheten att omskapa sig själv som handlande subjekt.

Efter denna introduktion kommer vi att redogöra för vår teoretiska förståelse av rasifiering, platskamp, aktivism och transcenderande identitetsprocesser. Vi kommer även att diskutera studiens metod och empiri. Därefter beskriver vi organisationen Megafonens framväxt i relation till en större samhällelig kontext. Detta följs av Jasmines berättelse, där vi analyserar hur hon artikulerar sina personliga upplevelser och sitt engagemang i Megafonen i relation till rasifiering, segregation och genusmönster. Här synliggörs hur hennes belägenhet som ung, kvinna och förortsbo skapar en situerad kunskap som är både en orsak till och en förutsättning för den egna aktivismen. I vår avslutande diskussion lyfter vi fram hur transcenderande aspekter av förortsrörelsens platskamp möjliggörs genom relationen mellan individuell erfarenhet och kollektiv handling.

\section{Rasifiering, platskamp och transcenderande identitetsprocesser}

Den förortsrörelse som uppkom i Sverige under det första decenniet av 2000-talet består i huvudsak av olika ungdomsledda organisationer. Den ungdomsaktivism som kommer till uttryck i denna rörelse är i grunden ett svar på en samtida nyliberal ekonomisk utveckling som bland annat yttrar sig genom att segregationen byggs in i en social och ekonomisk polarisering av stadsrummet. Ungdomarnas erfarenheter präglas av social underordning och kulturell stigmatisering som är nära förbundna med hur dessa sociala platser skapats genom rasifierande processer.

Rasifiering bygger på sammanlänkade politiska, ekonomiska, sociala och kulturella processer som leder till hierarkisk maktordning i samhället 
genom att individer och grupper marginaliseras, exploateras och stigmatiseras kulturellt. De drabbade tillskrivs stereotypa identiteter baserade på negativa föreställningar kopplade till hudfärg, kultur och religion. Rasifiering kan spåras till både kolonialismen och den historiska utvecklingen av kapitalismen (Miles I993). Maktrelationer sprungna ur en kolonial tid lever i dag vidare bland annat genom föreställningar om oföränderliga och avgörande kulturella och/eller biologiska skillnader, och de bidrar till att upprätthålla ojämlikheter i samhället. De yttrar sig genom skillnadsskapande processer som normaliserar ojämlikheter i offentlig representation, boende, arbete med mera. Individer och grupper underordnas genom ett diskursivt skapande av annanhet (Ålund 20I2). ”De andra” blir den nödvändiga konstitutiva utsidan som låter "oss" definiera oss som ett "vi" och som samtidigt hindrar "dom" från att uppnå samma status, positioner och socioekonomiska villkor som "vi" (Miles 1993).

Rasifieringsprocesser har en påtaglig platsdimension i Sverige. Här spelar multietniska storstadsförorter en central roll. Dess befolkning skapas ofta som de andra, inte minst i olika massmedier, då majoriteten av de som flyttat in och bor kvar i dessa områden i dag är svenskar med utomvästerländsk bakgrund (Ristilammi 1994; Andersson 2007). Diskursen om de multietniska förorterna och deras invånare har under flera decennier normaliserat berättelser om avvikande kulturella identiteter i förhållande till en föreställd homogen svensk kultur, där vissa stadsdelar blir till områden som symboliskt skrivs bort från nationen (Lundström 2007).

Dessa platser är samtidigt sociala rum ur vilka motberättelser föds och leder till att nya kollektiva identifikationsprocesser skapas, en utveckling som har varit central för förortsrörelsens framväxt som en ny urban rättviserörelse. Den platskamp som här förs kombinerar krav på social rättvisa och jämlikare fördelningspolitik med viljan att uppvärdera områdenas sociala och kulturella status. Även om den urbana rättviserörelsen inte är partipolitisk, så är den inte desto mindre politisk. Det är viktigt att analysen av ungdomars aktivism sker bortom en snäv förståelse av det politiska. Att ungdomar organiserar sig för att hävda sin rätt, att de har en vilja till förändring, att de gör motstånd och utkräver ansvar är också tecken på deras djupa politiska engagemang i samhället (Thomson m.fl. 
2004, s. 22I). Fethi Mansouri och Maša Mikola (20I4) påpekar att denna typ av ungdomsaktivism också kan ses som en iscensättning av ett nytt och engagerat medborgarskap.

Som Engin F. Isin (2009) påpekat är motstånd och kravställande grundläggande aspekter av det som kallas medborgarskap. Ur detta perspektiv är medborgarskap inte enbart en formaliserad position som erhålls genom nationalstatens juridiska apparat. Medborgskap handlar också - och kanske snarare - om iscensatta, "utagerade processer" (enacted processes) som sätter fokus på hur människor som aktiva subjekt handlar för att bli medborgare (Isin 2009). Olika gruppers kamp för social och ekonomisk rättvisa har genom tiderna varit centrala i skapandet av medborgarskapet. Isins teoretiska förståelse av medborgarskapet för samman begreppet medborgare med diskussioner om agens, där att göra anspråk på rättvisa, att bryta habitus och agera på ett sätt som stör den etablerade maktordningen också är att göra medborgarskap. För Isin illustrerar detta hur själva agerandet skapar nya subjektspositioner och hur denna "aktivistmedborgare" sätter "nya platser för protest, tillhörighet, identifikation och kamp" på kartan, platser som skiljer sig från medborgarskapets traditionella platser såsom valdeltagande (Isin 2009, s. 37I, vår översättning). Det är ur denna teoretiska förståelse, där vikten av agens, kravställande och kamp framträder som central för konstruktionen av en medborgarposition, som vi närmar oss den nya förortsrörelsens platskamp.

Samma teoretiska fokus på görande och agens som informerar vår förståelse av medborgaskap orienterar också vår förståelse av hur individer blir aktivister. I uppkomsten av en social rörelse sprungen ur de krav på social rättvisa som ställs av ungdomar tillhörande en postmigrantgeneration från socioekonomiskt utsatta områden, finns en grundläggande dimension som handlar om viljan att på ett nytt sätt skapa sig som subjekt i samhället. Denna dimension närmar vi oss med hjälp av Stuart Halls (1990) teoretiska förståelse av begreppen "att vara" och "att bli" (being/becoming). I Halls (1990) diskussion om den koloniala erfarenheten av svarta människor i diaspora förhåller han sig kritiskt till en essentialiserande förståelse av identitet. Därmed vill han ta avstånd från en uppfattning där invandrares identiteter antas ha en ursprunglig och 
oföränderlig kärna med ursprung i deras "hemländer”. I stället påpekar han att identitet, eller de subjektspositioner som vi identifierar oss med, inte kan annat än att vara i ständigt vardande. I denna teoretiska förståelse av identitetsprocesser förs med andra ord att vara samman med att bli. Identiteter är föränderliga eftersom individens positionering av sig själv i termer av identitet beror på hur vederbörande identifierar sig med olika sociala grupper, en identifikation som i grunden alltid villkoras av hur individer och sociala grupper är positionerade - genom samhällets maktordning och inom dominerande representationsregimer. Brian Bourke (20I4) visar i sin läsning av Stuart Hall (1990) hur man genom att se identitetsprocesser som subjektspositioner sammanför objektivt med subjektivt, struktur med agens samt erfarenhet med perception och handling. Skapandet av individuell identitet görs alltid inom ramarna för identifikationsprocesser med större sociala kollektiv och därmed inom ramarna för maktrelationer av både materiell och symbolisk karaktär. Där skapas sociala grupper som överordnade eller underordnade utifrån kön, ras, etnicitet, klass med mera. Men individuella ställningstaganden om vem man är som individ och gruppmedlem är inte bara förankrade i större samhälleliga strukturer, de kan också aktivt spjärna emot dessa och åstadkomma rubbningar i ordningen och förflyttningar mellan olika sociala positioner i strävan efter att ändra villkoren för sitt eget varande (Bourke 20I4). Samma spår följer det Ted Rutland (20I3) kallar aktivist i vardande (activist in the making), där aktivistpositionen diskuteras som en reflexiv process kopplat till skapandet av en politisk subjektivitet; en process som innebär ett "alltid oavslutat arbete med sig själv" (Rutland 2013, s. IOOI).

Det är utifrån detta teoretiska ramverk som vi vill närma oss Megafonens historia och Jasmines berättelse om sin aktivism. Med hjälp av Isins tankegångar om medborgarskapande och Halls och Rutlands tankegångar om identitetsskapande vill vi knyta samman det objektiva och det subjektiva, erfarenhet och agens. Genom sammanlänkningen av det individuella narrativet och det kollektiva handlandet kommer vi att illustrera hur det personliga och det politiska är intimt sammanvävda i de transcenderande identitetsprocesser som Megafonens aktivism möjliggjorde. 


\section{Metod och empiri}

Författarna har sedan 2014 samlat empiri om den nya förortsrörelsen genom deltagande observation, intervjuer, internet och artiklar. ${ }^{I}$ Sammanlagt har ett trettiotal intervjuer genomförts med nyckelpersoner inom rörelsen och berörda tjänstemän. Dessa intervjuer och artiklar kommer här att utgöra grunden för beskrivningen av Megafonens historia. Författarna har valt att fokusera på Megafonen-medlemmen Jasmines livsberättelse i denna artikel. ${ }^{2}$ I enlighet med Robert K. Yins (2003, s. I3) definition av en fallstudie använder vi Jasmines berättelse om sin aktivism som "en empirisk undersökning som utforskar ett samtida fenomen inne i sin verkliga, levda kontext, särskilt när gränserna mellan fenomen och kontext inte är helt tydliga” (vår översättning). Denna förståelse av fallstudie innebär att vi i Jasmines livsberättelse ser hur gränsen sammanvävs mellan egna erfarenheter och den levda kontexten, i det här fallet förorten. I Jasmines berättelse vill vi lyfta fram hur hon själv formulerar förbindelselänkar mellan det levda livets kontext, aktörskap och struktur, alltså hur samspelet ser ut mellan självpositionering och positionering relaterad till strukturella förhållanden och maktordningar i samhället, baserade på bland annat etnicitet eller ras, kön och klass.

Jasmines livsberättelse innehåller många av de centrala ämnen som ett tiotal andra aktivister har tagit upp i våra intervjuer. Dessa är kopplade till erfarenheter av samhällelig marginalisering och rasifierad stigmatisering. Vi låter här Jasmines livsberättelse vara ett exemplariskt fall av vad som kan kallas en "tillhörighetens politik" (politics of belonging) (Ålund 20I4). Därmed vill vi belysa hur konstruktionen av tillhörigheter är strukturellt villkorad och hur identifikation med andra "andra" kan skapa möjligheter för solidaritet och inkluderande förändring, något som Megafonen som organisation också är ett exempel på.

Liksom Floya Anthias (2002, s. 50I-502) ser vi på berättelser, eller narrativ, som en form av social handling som innebär ett aktivt deltagande i skapandet av subjektspositioner - en positionalitet. Positionaliteten skapas i ett spänningsfält mellan agens och struktur, det vill säga både

I. Detta har skett med finansiering från Vetenskapsrådet (projektnummer 2013-7277IO2936-I4 och 72I-20I3-885) och Formas (projektnummer 250-20I3-I547).

2. Informanternas namn har anonymiserats. 
de processer genom vilka individer och grupper identifieras av andra, och de processer av självidentifikation varigenom individer och grupper själva formar eller definierar vilka de är. För Anthias sker dessa identifikationsprocesser genom konkreta praktiker på en intersubjektiv nivå, en organisationsnivå och på en representationsnivå. Detta perspektiv förbinder Jasmines narrativ som aktivist i vardande med Megafonens tillblivelse som ett kollektiv av aktivistiska medborgare. Här synliggörs förankringen av personliga erfarenheter inom ett bredare socialt och historiskt sammanhang med dess utmärkande sociala maktrelationer (Bathmaker 20Io).

I det följande redovisar vi Megafonens historia och dess övergång från att vara en organisation för aktiva medborgare till en organisation för aktivistiska medborgare. Det som gör Megafonen viktig i sammanhanget är att organisationen genom sin närvaro i den offentliga debatten - särskilt som "ortens" språkrör under upproret 20I3 - blev till en förebild för många unga aktivister inom den svenska förortsrörelsen.

\section{Megafonen: platskamp och medborgarskapande aktivism}

Megafonen som organisation föddes i Stockholmsförorten Husby i slutet av 2008, ur den frustration som en grupp ungdomar kände inför presssens skildring av Ahmed Ibrahim Alis död. Ali var en mycket omtyckt och engagerad ung man i Husby som miste livet när han försökte intervenera $\mathrm{i}$ ett bråk. I pressens knappa rapportering kom hans död att kopplas till en "uppgörelse i kriminella kretsar", något som snart visade sig vara felaktigt (SvD 2008). Den kriminelle invandrarkillen, som en figur i "mediearkivets typgalleri", är här en av de stereotyper som villkorar förståelsen av förorten och dess invånare (Brune 2005). Det faktum att Alis död kopplades till kriminalitet väckte starka reaktioner i Husby och ledde till att en grupp ungdomar organiserade sig för att försöka bekämpa de krafter som driver fram stigmatiseringen av deras område. Det illustrerar hur aktivismen som Megafonen representerar från första början växer fram ur ett behov av självpositionering gentemot en offentlig stigmatisering av förorten.

Ett av de första projekt som genomfördes var utgivningen av ungdomstidskriften Nuförtiden som kom ut under hösten 20IO, finansie- 
rad genom annonser betalda av lokala sponsorer samt Hyresgästföreningen. I denna tidskrift skriver Megafonens medlemmar bland annat om den mediala stigmatiseringen av deras område, om arbetslöshet och om lokala förebilder. I tidskriften presenteras Megafonen som "en ungdomsorganisation som arbetar för att stärka de ungas delaktighet och politiska inflytande på Järva” (Megafonen 2oroa, s. 2). Den inledande artikeln, skriven av Basar Gerecci, riktar kritik mot avsaknaden av ungdomars röster i det då pågående Järvalyftet, och uppmanar till organisering för att åtgärda denna brist:

Järvalyftet är inget flyktigt projekt i välgörenhetssyfte. Satsningen kommer att förändra den plats som vi vuxit upp i så till den grad att vi snart kan vara främlingar i vårt eget hem. Det är skäl nog att organisera och engagera sig: ingen annanstans är vårt inflytande och arbete viktigare än här. Järvalyftet är stort, byråkratisk och krångligt - men om vi blir många kan vi påverka. (Megafonen 20IOa, s. 4.)

Järvalyftet är namnet på en planprocess påbörjad 2006. Svenska Bostäder fick i uppdrag av Stockholms stad att undersöka hur bostadsmiljön och den socioekonomiska situationen kunde förbättras i de socioekonomiskt utsatta områden som ligger på det så kallade Järvafältet i Stockholm, där förorterna Husby, Akalla, Tensta och Rinkeby ingår (Svenska Bostäder 20I8). Hösten 2007 beslutade stadshuspolitikerna enhälligt om ett långsiktigt program för upprustningen av dessa områden.

Järvalyftets utvecklingsprogram kritiserades tidigt av de boende i området och av den politiska oppositionen (Luthander 2008). Kritiken handlade om bristen på information till allmänheten och om brist på demokratiskt deltagande i planeringsprocessen. Detta ledde till en uppmärksammad protestkampanj där Megafonen kom att ingå. I en retrospektiv betraktelse menar en av Megafonens grundare, Rami Al-Khamisi (2015, s. I67), att dessa demonstrationer var viktiga för framväxten av en ny förortsrörelse. I fokus för denna nya sociala rörelse stod bekämpandet av de politiska och ekonomiska processer som leder till en utarmning av multietniska förorter.

För att öka förtroendet för satsningen inledde det kommunala bostadsbolaget Svenska Bostäder, som var ansvarigt för den fysiska renoveringen, 
en serie samtal med de boende i Järvaområdet. Denna satsning fick namnet Järvadialogen. Megafonen uppmärksammade dock att ungdomarna inte var representerade i dialogen, och organisationen blev inbjuden av Svenska Bostäder att samla in ungdomars tankar och åsikter om satsningen. Det resulterade bland annat i rapporten Att vara ung i Husby (Megafonen 20Iob), som baserades på fokusgruppsintervjuer med ett 40-tal ungdomar i åldersgruppen I8-25 år. Förslagen som formuleras i denna rapport lyfter fram vikten av investeringar i utbildning, sysselsättning och välfärdstjänster snarare än fysisk förnyelse, som de inte ansåg vara en prioritet. Varken rapporten eller de samtal som skedde inom Järvadialogen hade, ur Megafonens perspektiv, någon större inverkan på planeringsprocessen. I en debattartikel i Dagens Nyheter problematiserar Megafonens medlemmar Rami Al-Khamisi och Basar Gerecci (2012) vad de menar är demokratiska brister i planeringsprocessen:

Den demokratiska uppgiften har svikits på det mest nonchalanta vis. När Järvadialogen först hölls i Husby samlades flera tusen synpunkter. Det är dessa dialogdagar och synpunkter som stadens makthavare stolt marknadsför som ett demokratiskt underverk. Att det var bra uppslutning på dessa dialogdagar stämmer, men hur mycket är en dialog värd utan handling och faktiska åtgärder? Hur kan demokratin reduceras till en sifferlek, i stället för att handla om medborgarnas inflytande över verkliga politiska beslut? Sedan den första dialogen hölls våren 2009 har vitala verksamheter för området lagts ned eller privatiserats (Husby träff, posten, vårdcentralen m.fl.), trots befolkningens eniga motvilja. Inte ens de enklast genomförbara förändringarna, såsom utökade resurser för fritidsverksamhet eller uppfräschning av idrottsanläggningar, har genomförts. När vi sedan uttrycker missnöjet till våra lokala politiska representanter, är de lika bortförda som oss och hänvisar tillbaka till den slutna beslutsprocessen i stadshuset.

Al-Khamisi och Gerecci drar slutsatsen att det finns ett behov av förnyelse i de institutioner som borde garantera Järvas medborgare fulla demokratiska rättigheter och möjligheter att påverka de politiska beslut som berör dem själva.

Efter dessa erfarenheter kom organisationen att engagera sig i en rad protestaktioner som på olika sätt uppmärksammade demokratiska brister i offentliga institutioners hantering av åtgärder i förorten. Ett exempel är ockupationen av samlingslokalen Husby Träff under januari 20I2. Husbyträffen drevs av Röda Korset, i lokaler som ägdes av Svenska 
Bostäder. Bakgrunden till ockupationen var att verksamheten i denna mycket populära samlingslokal för lokala föreningar efter ett beslut i stadsdelsförvaltningen skulle flyttas till en annan lokal med sämre förutsättningar att fungera som samlingspunkt. Beslutet hade inte varit förankrat bland de berörda föreningarna, som uppfattade detta som ännu ett i raden av beslut som ledde till en utarmning av området. Ett nätverk av föreningar - i vilket Megafonen ingick - och Husbybor kallat "Husby kräver respekt" bildades för att protestera mot beslutet. Ockupationen av samlingslokalen varade i två veckor. Den gick från att vara en protest mot beslutet att flytta möteslokalen till att bli en protest riktad mot nedskärningar i området som för Megafonen inneburit försämring eller nedläggning av skolor, vårdcentraler, postkontor, kommunala kontor, Försäkringskassan med mera (Megafonen 20I2). När organisationen Pantrarna för upprustningen av förorten - en systerorganisation till Megafonen baserad i Göteborg - år 2012 anordnade en förstamajdemonstration i Göteborgsförorten Biskopsgården inbjöds Megafonen att hålla tal. I sitt tal framhöll Megafonen-medlemmen Sepideh ockupationen som en för organisationen viktig läroprocess:

I SVT:s morgonsoffa pratar de gärna om hur man ska satsa på våra förorter. Men ändå fortsätter våra förorter och dess befolkning att diskrimineras. När våra förorter rustas ned, så måste vi som boende stå upp. När våra politiker beslutar om att skära ned resurserna för vårt kulturhus, så stod folket i Husby emot. Ockupationen som varade i två veckor var ett bevis för vår egen förmåga att försvara våra egna rättigheter. Något som ockupationen lärde oss, är att den makt som politikerna har är beroende av hur medborgarna väljer att bemöta den. Frihet är något man tar, inte något man får. Det är bara förorten som kan lösa förortens situation. Vi är här på första maj för att visa vår gemensamma kamp, oavsett om det är i Biskopsgården eller Husby. (Videoinspelning, I maj 20I2.)

I detta tal presenteras ockupationen som ett tillfälle som gav viktiga lärdomar. Det som specifikt lyfts fram är att politisk makt ytterst är beroende av dess legitimitet bland medborgarna. Lösningen på "förortens situation" ligger i den "gemensamma kampen".

Ytterligare ett exempel på Megafonens deltagande i aktioner där demokratiska brister i offentlig förvaltning uppmärksammas, är kampanjen Alby är inte till salu (AIS). Kampanjen är en reaktion på att Botkyrka 
kommun och det kommunala bostadsbolaget Botkyrkabyggen beslutade att sälja I 300 offentligt ägda lägenheter i kommundelen Alby till en privat hyresvärd. Ett nätverk av boende och organisationer började samverka för att förhindra utförsäljningen genom att få till en folkomröstning om beslutet. Några av de som engagerade sig i kampanjen kontaktade Megafonen. Erica, en ung kvinna boende i Alby som deltog i AIS, beskriver detta på följande sätt:

När vi började samla namnunderskrifter för Alby är inte till salu, började vi titta oss runt på vad som hände i Stockholm. Och andra som var aktiva sen en tidigare period började titta på oss, och vi började gå på varandras grejer och titta på varandras Youtube-klipp. Vi fick väldigt mycket inspiration. Jag kommer ihåg en grej som Basar som var med i Megafonen hade gjort en gång där de ockuperade, kraschade egentligen, en jätteflashig visning i Kista Tower för att påvisa att lägenheterna som byggdes där inte var till för folket, för att de var alldeles för dyra. [...] Man började träffas och sen så började man förstå också att deras kamp var också en del av vår kamp, för att de kämpade mot liknande saker, och vårt förtryck, det motståndet vi hade såg väldigt lika ut. Och de åkte från Husby, från Vällingby, från Hjulsta, alltså typ en timmes tunnelbaneresa för att samla namn med oss, och det fick oss att känna så här, shit, de här här är också en del av oss. [...] Och vi kände att det är bättre att tillhöra någonting större och att visa på att vi är eniga i vår kamp, och därför valde vi att bilda Megafonen Norra Botkyrka. (Intervju, 22 september 20I6.)

AIS lyckades samla in de 6500 namnunderskrifter som krävdes av kommunen för att initiera en folkomröstning, men valnämnden underkände en stor del av underskrifterna. Trots att kommunen genomförde försäljningen av lägenheterna blev kampanjen en viktig erfarenhet för de inblandande aktivisterna och kom att fungera som ett tillfälle att stärka av translokala allianser inom förortsrörelsen. Från att vara en organisation baserad i Husby växte Megafonen år 20I3 till en organisation med avdelningar i Rinkeby, Hässelby/Vällingby och Norra Botkyrka, områden som hör till de mest socioekonomiskt utsatta stadsdelarna i Storstockholm. De organiserade musikfestivaler, fotbollsturneringar och läxhjälp. En av de mer kända verksamheterna var föreläsningsserien Harakat till vilken aktivister, forskare och politiker inbjöds för att samtala med människor från närområdet. Genom ett intensivt internt arbete antog organisationen under denna tid ett politiskt program med sju punkter, med fokus 
på satsningar på utbildning, arbete och bättre samhällsservice i förorten (Megafonen u.å. a). I detta program sammanbinder Megafonen platskampen med bredare strukturella och institutionella villkor.

För allmänheten var det dock en annan händelse som Megafonen kom att förknippas med. Detta skedde i samband med det upplopp som startade i Husby efter att en 69-årig man, Lenine Relvas-Martins, sköts till döds i sin lägenhet i Husby av polisen under oklara omständigheter. Den 16 maj anordnade Megafonen en fredlig demonstration mot polisvåld, där de också formulerade krav på att de oklarheter som rådde kring mannens död skulle utredas. Den I9 maj 2013 började ungdomar bränna bilar i området. Oroligheterna kom att pågå under en dryg vecka, och spred sig till förortsområden i andra städer. Det var inte första gången som Sverige drabbades av ett urbant upplopp, men det var första gången det fick internationell uppmärksamhet (Schierup m.fl. 20I4). Den 20 maj 2013 anordnade Megafonen en presskonferens för att ge sin syn på oroligheterna. Det är talande för den status som organisationen hade lyckats uppnå att så många journalister kom. Megafonens medlemmar pekade på den ackumulerade effekten av social utslagning, diskriminering, polisiärt våld och stigmatisering av förorten som det avgörande skälet till att det brann i Husby. Megafonens medlemmar fick stöd av vissa forskare och politiker, men blev av andra aktörer närmast utpekade som medskyldiga till upploppet. Detta bemötte organisationen i ett uttalande på sin hemsida där de klargjorde sin ståndpunkt:

Megafonen startar inte bränder. Vi anser att dessa inte är rätt metod för långsiktig förändring. Men vi vet att det är en är en reaktion på brister i samhället. Arbetslöshet, bristfälliga skolor och strukturell rasism är bakomliggande orsaker till det som sker i dag. Megafonens lösning är det konstruktiva motståndet genom social upprustning. (Megafonen 2013.)

Genom att ta på sig rollen som "förortens röst" i den intensiva och politiserade debatt som följde efter upploppen hamnade Megafonen i fokus på ett sätt som orsakade stor stress för dess medlemmar, och organisationen valde att inte längre vara lika aktiv i den offentliga debatten. I dag fortsätter Megafonen att jobba med ungdomar i socioekonomiskt utsatta områden, till exempel genom scenkonstprojektet Ortens verklighet. 
Megafonens historia skriver in sig i den sociala rörelse som växte fram bland ungdomar och unga vuxna under 2000-talets första och andra decennium i den svenska urbana periferin. I organisationens historia kan vi spåra omvandlingen från en organisation med fokus på att främja ett aktivt medborgaskap, det vill säga att stärka Järvafältets ungdomars delaktighet i initiativ igångsatta av etablerade politiska aktörer, till att bli en organisation som praktiserade ett aktivistiskt medborgarskap. Detta betyder, för att tala med Isin, att organisationen utvecklades från att bestå av "aktiva medborgare som agerar utifrån redan givna föreskrifter, som till exempel i frågor rörande valdeltagande, betalande av skatter och att ta värvning" till att, i samband med att de konfronterade bristen på demokratiskt utrymme i offentliga beslutsprocesser, positionera sig som "aktivist-medborgare" (Isin 2009, s. 38I).

En djupare förståelse av denna förvandling kräver en kvalitativ undersökning av de erfarenheter och tankar som de unga aktivister som utgjorde Megafonen hade, något Jasmines berättelse illustrerar.

\section{Förorten och ungdomars identitetsformeringar}

Det finns i dag en rad kvalitativa studier som synliggjort de effekter som etnisk/rasifierad urban segregation och territoriell stigmatisering har på barns och ungdomars livsvillkor och identitetsformeringar i urbana miljöer (se t.ex. Ålund 1997; Sernhede 2002; Lundström 2007; Bäckman 2009; León Rosales 20I0). I denna litteratur påvisas hur barns och ungdomars identitetsformering på olika sätt villkoras av segregation och av stigmatiseringen av socioekonomiskt utsatta områden, men även hur barn och ungdomar utvecklar strategier för att handskas med dessa villkor. Vi kommer nu att närma oss Jasmines berättelse utifrån ett liknande fokus.

\section{Jasmines berättelse}

Jasmine är född och uppvuxen på Järvafältet, i Akalla och Kista, med föräldrar utvandrade från Mellanöstern. ${ }^{3}$ Hon fick mycket stöd av sina föräldrar som båda hade medelklassbakgrund med akademiska studier

3. Jasmines berättelse baseras på en intervju genomförd I8 februari 2015 . 
bakom sig. Den vikt föräldrarna ger utbildning får en extra tyngd av deras migrationshistoria:

För dem var det viktigt att vi utbildas ... deras bakgrund är att de är akademiskt utbildade, de har en lön, de har kämpat. Pappa har en politisk bakgrund där han flydde under revolutionen och där han bodde i Österrike ett par år och där han studerade tyska, men han bodde på parkbänkar för att han inte hade råd ... Hans föräldrar ville att han skulle bo kvar men han var revolutionären i familjen.

Jasmine berättar att i årskurs fyra tyckte hennes föräldrar att den skola hon gick på började fungera allt sämre, "man började lägga ner mindre resurser på den, lärarna slutade så det började bli fler vikarier”. Föräldrarna valde att flytta henne till en skola $\mathrm{i}$ innerstaden.

Att gå i en skola i innerstaden innebar att hon började se annorlunda på sitt eget bostadsområde. De budskap hon mötte i massmedier om sin uppväxtort, med "våldtäkter, rån och mord i förorten", väckte en rad frågor kring vem hon var och var hon bodde: "Min självkänsla började brytas ned successivt: Vem är jag? Varför bor jag i förorten? Vem vill jag vara?" I hennes berättelse kopplas dessa tankar samman med ett ifrågasättande av föräldrarnas val:

Och så började jag bli arg på mina föräldrar. ”Varför bor vi här? Jag skäms, jag kan inte prata med mina kompisar för att de säger att jag bär kniv. Jag vill inte bo här, alla blir mördade och våldtagna, jag vill inte vara här." Och mina föräldrar lugnade ner mig varje gång och sa: "Peka finger åt dem." [...] "Antingen väljer du att peka finger åt dem eller så väljer du att bjuda hem alla och så får vi se om de har samma fördomar." Det vi gjorde då är att vi tog ett beslut i familjen att "nu bjuder vi hem hela klassen".

Förhoppningen att skapa en annan förståelse av området genom att presentera sin familj och sina grannar för skolklassen föll väl ut. För Jasmine själv ledde dock erfarenheten så småningom till nya funderingar: "Varför behövde jag hävda mig själv? Varför behövde jag bevisa att mitt område minsann är ett bra område?”

Hennes funderingar kring sin egen identitet var också kopplade till att hon i skolan i många sammanhang blev påtvingad en identitet som hon inte ville kännas vid, positionen som "invandrartjej": 
Av den här klassiska välviljan, det har aldrig hänt under svenskalektionerna, men [läraren] lyfter upp mitt papper. Jag har fått högsta betyg. Han frågar: "Hur kommer det sig att du, med din invandrarbakgrund, får högst betyg i skolan?" Och alla tittar på mig, och jag tänker: "Jag har pluggat precis som alla andra." "Du pratar inte svenska hemma, inte sant?" ”Nej", säger jag, "jag pratar persiska." "Hur kommer det sig? Det är ju jättehäftigt, och alla ni andra, som inte har fått bra betyg, hur kommer det sig att ni inte har fått det här betyget som Jasmine med sin invandrarbakgrund har fătt?” Helt plötsligt blev jag annorlunda [...] och jag kände att mina klasskompisar började helt plötsligt titta på mig med andra ögon.

Jasmines berättelse illustrerar en påtvingad positionalitet (Franks 2002, s. 42), där hon trots lärarens förmodade goda intentioner skapas som annorlunda, som någon som skrivs ut från ett normerande "vi” i klassrummet. Lärarens kommentarer är ett exempel på hur diskriminering kan ske i skolans vardag, där en i samhället spridd förståelse av "förorten" och "invandrare" villkorar hur ungdomar ifrån dessa områden bemöts och betecknas. Det är med bakgrund i dessa erfarenheter som Jasmines egna frågor formuleras i hennes berättelse, där kärnan i de frågor hon ställer sig handlar om jämlikhet: varför behandlas hon inte som alla andra?

Hennes reflektioner kan samtidigt ses som ett kritiskt deltagande i skapandet av den egna positionaliteten, eller som hon uttrycker det, den egna självbilden. Dessa erfarenheter och funderingar utgör ryggraden för framväxten av en politisk subjektivitet, där hon så småningom väljer att engagera sig i Megafonens platskamp.

I Jasmines berättelse finns samtidigt en påtaglig kontinuitet $\mathrm{i}$ form av föräldrarnas kamp för social rättvisa, deras erfarenheter av migration och deras stöd till sina barn. Föräldrarnas migrationshistoria är i sig en källa till lärdom och reflektion:

Att få höra att pappa satt i fängelse, tog sig till Sverige och även om arbetet, han har haft det jättetufft med jobbet. Att han alltid har tagit strid och han har alltid varit väldigt mån sen jag var liten att: "du ska känna till dina rättigheter, du ska kräva dina rättigheter, du ska aldrig låta någon trakassera eller diskriminera dig på grund av din bakgrund, på grund av ditt kön, på grund av någonting, stå på dig, Jasmine!" 
Föräldrarnas migrationshistoria och erfarenheter i Sverige framträder som avgörande för skapandet av Jasmines positionalitet som kvinna på egna villkor, och för hennes kritiska perspektiv på samhället. Även hon själv kopplar föräldrarnas erfarenheter till sitt eget ifrågasättande av den stigmatisering och diskriminering hon kom att uppleva:

Pappa var väldigt mån om att. så här: "Tänk konstruktivt, det kritiska tänket vad gäller var du läser det någonstans? Du läser i en tidning, men har du någonsin bemötts utav något av det här själv?” Så han fick mig att börja tänka kritiskt. Men också mamma som jobbade mycket på att: "Skäms inte, stå emot och låt oss på nått sätt förändra deras syn på, eller de fördomarna, spräcka deras fördomar."

Jasmine förklarar att denna kombination av integritet och kämpaglöd resulterade i att hon blev "mycket engagerad som person". Vikten av att bekämpa fördomar och diskriminering lärde hon sig från sina föräldrar. Att ta strid om det är nödvändigt, att inte tillåta någon att behandla henne sämre eller att underordna henne. I linje med Rutland (2013, s. IOoI) ser vi detta som att hon använder familjebakgrunden i ett arbete med självet, där föräldrarnas erfarenheter blir centrala för hur hon artikulerar framväxten av sin politiska subjektivitet. Föräldrarnas intresse för politik bidrog, enligt Jasmines berättelse, till hennes eget lokalpolitiska intresse och till hennes aktivism i Megafonen: "Jag följde alla nyheter kring vad som händer i världen. Pappa var alltid med vid middagsbordet, vi skulle prata politik. Jag började se vad som händer i området jag växer upp i. Tidigare var jag inte alls insatt, inte alls intresserad, till att det blev det som blev viktigast för mig. Så jag började kontakta alltifrån Kistaloppet, Husby Marathon till Megafonen som hade startat då.”

\section{Vägen hem}

Jasmine kom i kontakt med Megafonen genom föreläsningsverksamheten Harakat som organisationen anordnade i samarbete med Rädda Barnen. Harakat, som på arabiska betyder rörelse, beskrivs på Megafonens hemsida som "Tunga föreläsningar och diskussioner som berör samhällsfrågor som är viktiga för oss i våra orter" (Megafonen u.å. b). Föreläsare som var experter på ämnen som organisationen ville fördjupa sig i bjöds in till en öppen diskussion med frågestund och fika. I fokus 
stod inhämtandet av kunskap för att utveckla organisationen. Många av föreläsningarna drog till sig flera hundra personer, både unga och vuxna. Från att i början mest vara en åhörare började Jasmine engagera sig i allt fler aktiviteter som startades:

Jag var nyfiken, jag var där, alltså på alla deras möten ville jag sitta med. Jag ville bara lyssna, jag hade inget att säga, jag ville bara lyssna. Och alla initiativ som togs för festivaler och till läxhjälp, till CV-verkstäder, till ockupationer, till demonstrationer så fanns jag med. Så det var mitt sätt att liksom egentligen komma in i det här och förstå.

Diskussioner som hjälpte boende i området och Megafonens medlemmar att förstå varför det såg ut som det gjorde i samhället blev centrala i Harakats utbildningssammanhang. För Jasmine blev det en läroprocess kopplad till de egna erfarenheterna och en källa till egen förståelse "av sociala motsättningar" (Crenshaw 20II, s. 232). Detta liknar hon vid att hitta hem:

Så jag började ju känna att jag hörde hemma nånstans. Under den perioden ville man få sin röst hörd. Så jag var med i den organiseringen, jag var inte den huvuddrivande utan jag började lära mig. Det var för mig ett sätt att lära mig mer om varför, liksom.

Hon blev särskilt angelägen om att delta i Megafonens pedagogiska arbete. Genom sitt arbete i Megafonen kom Jasmine i kontakt med det etablerade civila samhällets aktörer. Hon fick möjligheten att inom ramarna för en större icke-vinstdrivande organisation arbeta med att stödja ungdomar i området och arbeta för att öka unga flickors representation i den lokala offentligheten. Genom detta arbete och genom sin aktivism inom Megafonen kom hon att möta många ungdomar och föräldrar, möten som hjälpte henne att se de strukturella dimensionerna i hennes egna erfarenheter:

[D]e ungdomarna var ju de som hängde på torget och kände: "Hur kommer det sig att vi söker jobb och inte får jobb? Hur kommer det sig att jag har blivit kroppsvisiterad åtta gånger men alltid varit oskyldig? Hur kommer det sig?” Det var mycket frågor. "Hur kommer det sig att man rustar upp vårt område utan att fråga oss? De bygger broar, vi vill inte ens ha broar, vi vill ha fritidsgårdar." 
På det sättet startade ju Harakat. Jag fick komma i kontakt med föräldrar, för mig var det väldigt främmande. Jag hade inte hört eller tänkt på det perspektivet tidigare. Och höra deras utmaningar och de konflikter de brottas med dagligen när läxhjälpen brister i skolan eller när skolan inte fyller de funktioner, hur man mår som förälder och när man inte vet vart man ska vända sig eller när man inte kan vara det stödet till sina barn.

Mötet med ungdomar och föräldrar inspirerade Jasmine att tillsammans med andra av Megafonens medlemmar starta en läxhjälpverksamhet för barn i närområdet. Detta kom att ta mycket av medlemmarnas tid. Arbetet med Megafonens pedagogiska satsningar kom också att väcka många frågor hos henne som anknöt till de frågor hon själv länge ställt sig:

Med min nyfikenhet, jag ville ju lära, jag ville höra föräldrarna berätta, jag ville höra ungdomarna berätta som har blivit kroppsvisiterade åtta gånger utan anledning, och förstå hur det är. Och så kunde jag relatera till det när jag sen började förstå mina gymnasieår: Varför trodde de, varför ville de aldrig komma hem till mig? Varför blev jag kallad adopterad? Varför lyfte han mitt svenskaprov och jag blev invandrartjejen med bra betyg? Varför? Och så började jag förstå.

Från tidigare engagemang och framgång inom idrotten hade hon sedan länge haft med sig en övertygelse om att "du kan om du vill", en övertygelse om att framgång berodde på individuell ansträngning. Detta var en övertygelse som hon kom att ompröva genom sitt arbete med Megafonen:

Den resan var jättevärdefull för mig, att från "du kan om du vill” till att så här: "Absolut, det är bra att du kan om du vill, men du har inte samma förutsättningar som någon annan och vi ska kräva våra rättigheter och samhället måste möta våra behov.” Det var någonting som jag inte hade med när jag började och som jag har lärt mig med tiden att förstå. Min uppväxt blev en kontext. Jag landade i min självbild också och hur min uppväxt har varit i relation till vad jag gör i dag liksom och varför jag valde att engagera mig i olika initiativ och rörelser.

Jasmines sammanfattar identifikationsprocessen i förhållande till Megafonen genom en reflexiv sammankoppling av rasifiering och självpositionering. I hennes berättelse framstår insikten om att vi inte har samma förutsättningar och att vi därför måste "kräva våra rättigheter" som något av det viktigaste som arbetet inom Megafonen gav henne - en insikt 
som också varit avgörande för att förstå de egna erfarenheterna och för att därigenom "landa i sin egen självbild". Hennes berättelse illustrerar hur negativa erfarenheter av rasifiering kan överbryggas genom kollektiva och självreflexiva processer - ett uttryck för hur det personliga är politiskt (Ålund 20I4). Att engagera sig i Megafonen blir här en form av social handling i skapandet av självpositionering (Anthias 2002). Känslan av hemmahörande som Jasmine beskriver, "Jag hörde hemma nånstans", är något hon själv varit med om att skapa genom ett enträget, självreflexivt "arbete med sig själv" (Rutland 20I3, s. IOOI). Det är här, i de funderingar och erfarenheter som synliggörs i Jasmines berättelser, som platskampen får sin resonansbotten. Det är i dessa erfarenheter som förortsrörelsen har sina rötter, det är här den hämtar sin kraft.

\section{Avslutande diskussion}

Vi har i denna artikel diskuterat de komplexa relationer som finns mellan rasifiering, aktivism och identitetsprocesser så som de synliggörs i Jasmines berättelse och den kollektiva platskamp som Megafonens aktivism står för. Med sitt program formulerar Megafonen ett politiskt ställningstagande som är i linje med vad Isin (2009) definierar som ett aktivistiskt medborgarskap: genom samhällskritiska offentliga debatter och manifestationer tog Megafonen på sig rollen som förortens röst och gick från att vara en organisation av aktiva ungdomar till att bli en del av en rörelse bestående av aktivistiska medborgare. Vi menar att denna utveckling också ska förstås som en effekt av erfarenhetsmässiga och relaterade emancipatoriska, identitetsskapande processer som de unga vuxna i Megafonen själva gick igenom. Jasmines berättelse visar på en motsvarande utveckling.

I Jasmines berättelse kan vi observera hur olika maktordningar och relaterade positionaliteter - ung kvinna med invandrarbakgrund, förortsbo, aktivist - samverkar eller krockar med varandra. I Jasmines sätt att skapa sig själv kan vi också se hur hennes föräldrar, med medelklassbakgrund från Mellanöstern, och deras erfarenheter från en annan tid och ett annat land blir centrala för hur hon lär sig att hantera ett samtida svenskt rasifierat samhälle. Denna förståelse av aktivism bland ungdo- 
mar med migrantbakgrund skiljer sig från de dominerande diskurserna om "invandrarflickor" och "invandrarpojkar".

Jasmine finner liksom Megafonen sin "väg hem" genom samhällskritiska och självreflexiva processer. Medan de söker svar på sina frågor blir de kritiska observatörer av sitt eget liv. På den vägen formas en kritisk medvetenhet om behovet att bryta strukturer och normer som utesluter dem själva från ett jämlikt demokratiskt deltagande. Dessa förvandlingar visar hur ett trancenderande identitetsskapande också är centralt för framväxten av ett aktivistiskt medborgarskapande. Personliga erfarenheter, som de som Jasmine vittnade om, kan genom en förankring inom ett bredare socialt kollektiv politiseras och ges en annan innebörd (jfr Bathmaker 20Io). Detta är grundläggande för att förstå förortsrörelsen som platskamp och dess vidare samhälleliga innebörder.

Avslutningsvis vill vi hävda att Megafonens historia och Jasmines berättelse synliggör hur ett samtida medborgarskapande har växt fram ur den kamp som förs i förortsrörelsen, av ungdomar som annars ofta uppfattas vara apolitiska. Denna aktivism måste ses som en del av samtida emancipatoriska processer, varigenom unga vuxna politiserar sina erfarenheter för att kräva sin rättmätiga plats i samhället.

\section{Referenser}

Abrahams, Naomi (1996) "Negotiating power, identity, family, and community: Women's community participation", Gender\& Society, Io, 6, s. 768-796. DoI: https://doi.org/I0.II77/0891243960I0006006

Al-Khamisi, Rami (2015) "Dialogen som blev en monolog”, i Lindholm, Teresa, Oliveira e Costa, Sandra \& Wiberg, Sofia (red.) Medborgardialog. Demokrati eller dekoration? Stockholm: Arkus.

Al-Khamisi, Rami \& Gerecci, Basar (20I2) "Järvas medborgare måste få påverka”, Dagens nyheter 3I mars 2012.

URL: http://www.dn.se/debatt/stockholmsdebatt/jarvas-medborgare-maste-fapaverka/ (5 mars 20I6)

Andersson, Roger (2007) "Ethnic residential segregation and integration processes in Sweden", i Schönwälder, Karen (red.) Residential segregation and the integration of immigrants. Britain, the Netherlands and Sweden. Berlin: Wissenschaftszentrum Berlin für Sozialforschung.

Anthias, Floya (2002) "Where do I belong? Narrating collective identity and translocational positionality", Ethnicities, 2, 4, s. 49I-5I4. DOI: https://doi.org/IO.II77/I468796802002004030I 
Bathmaker, Ann-Marie (20I0) "Introduction", i Bathmaker, Ann-Marie \& Harnett, Penelope (red.) Exploring learning, identity and power through life history and narrative research. London: Routledge.

Bourke, Brian (20I4) "Positionality. Reflecting on the research process", The Qualitative Report, 19, 33, s. I-9.

URL: https://nsuworks.nova.edu/tqr/volig/iss33/3 (I2 april 20I8)

Brune, Ylva (2005) "'Invandrare' i mediearkivets typgalleri”, i de los Reyes, Paulina, Molina, Irene \& Mulinari, Diana (red.) Maktens (o)lika förklädnader. Kön, klass \& etnicitet i det postkoloniala Sverige. En festskrift till Wuokko Knocke. Stockholm: Atlas.

Bäckman, Maria (2009) Miljonsvennar. Omstridda platser och identiteter. Göteborg: Makadam.

Crenshaw, Kimberlé (20II) "Postscript", i Lutz, Helma, Herrera Vivar, Maria Teresa \& Supik, Linda (red.) Framing intersectionality. Debates on a multi-faceted concept in gender studies. Farnham: Ashgate.

Edling, Jan (2015) Förorterna som Moder Svea glömde. Flexicurity/Verdandi. URL: http://www.verdandi.se/wp-content/uploads/20I5/ro/I5IOI4F\% 3 3\%B6rorterna-som-Moder-Svea-gl\% $\mathrm{C}_{3} \% \mathrm{~B} 6$ mde.pdf (25 januari 2018)

Franks, Myfanwy (2002) "Feminisms and cross-ideological feminist social research. Standpoint, situatedness and positionality: Developing cross-ideological feminist research", Journal of International Women's Studies, 3, 2, s. 38-50.

URL: http://vc.bridgew.edu/jiws/vol3/iss2/3 (I2 april 20I8)

Hall, Stuart (1990) "Cultural identity and diaspora", i Rutherford, Jonathan (red.) Identity. Community, culture, difference. London: Lawrence \& Wishart.

Harvey, David (2005) A brief history of Neoliberalism. New York: Oxford University Press.

Isin, Engin F. (2009) "Citizenship in flux: The figure of the activist citizen", Subjectivity, 29, I, s. 367-388.

DOI: https://doi.org/I0.1057/sub.2009.25

León Rosales, René (2010) Vid framtidens hitersta gräns. Om maskulina elevpositioner i en multietnisk skola. Botkyrka: Mångkulturellt centrum.

León Rosales, René \& Ålund, Aleksandra (2017) "Renaissance from the margins. Urban youth activism in Sweden", i Ålund, Aleksandra, Schierup, Carl-Ulrik \& Neergaard, Anders (red.) Reimagineering the nation. Essays on twenty-first-century Sweden. Frankfurt am Main: Peter Lang.

Lundström, Catrin (2007) Svenska latinas. Ras, klass och kön i svenskhetens geografi. Göteborg: Makadam.

Luthander, Per (2008) "Socialdemokraterna hoppar av Järvalyftet", Dagens Nyheter i8 mars 2008.

URL: https://www.dn.se/arkiv/stockholm/socialdemokraterna-hoppar-avjarvalyftet/ (23 mars 2018)

Mansouri, Fethi \& Mikola, Maša (20I4) "Crossing boundaries: Acts of citizenship among migrant youth in Melbourne", Social Inclusion, 2, 2, s. 28-37.

DoI: https://doi.org/I0.I7645/si.v2i2.I64

Megafonen (2010a) Nufortiden.

URL: http://megafonen.com/om/tidigare-aktiviteter/ (3 september 20I7) 
Megafonen (20IOb) Att vara ung i Husby. Åsikter och synpunkter från I8-25 åringar, rapport från Megafonen.

URL: http://jarvadialogen.episerverhosting.com/Documents/Megafonen-rapport2Isep-IIO.pdf (3 september 20I7)

Megafonen (20I2) Husby kräver respekt!', I9 januari 2012.

URL: http://megafonen.com/husby-kraver-respekt/ (3 september 20I7)

Megafonen (2013) Uttalande om Megafonens roll under förortsrevolterna, 2I maj 2013.

URL: http://megafonen.com/uttalande-om-megafonens-roll-under-

forortsrevolterna/ (3 september 2017)

Megafonen (u.å. a) Megafonens program.

URL: http://megafonen.com/om/politiskt-program/ (23 januari 20I8)

Megafonen (u.å. b) Harakat.

URL: http://megafonen.com/kultur/harakat/ (23 januari 2013)

Miles, Robert (1993) "The contradictions of racism", i Nathan, Ove, Farver, Ole \& Strange, John (red.) Rescue -43. Xenophobia and exile. Articles from the conference at the University of Copenhagen 3-5 October 1993. Köpenhamn: Munksgaard.

Ristilammi, Per-Markku (1994) Rosengård och den svarta poesin. En studie i modern annorlundahet. Stehag: Symposion.

Rutland, Ted (2013) "Activists in the making: Urban movements, political processes and the creation of political subjects", International Journal of Urban and Regional Research, 37, 3, s. 989-IOII. DOI: https://doi.org/IO.IIII/j.I468-2427.20I2.oIIIo.x

Schierup, Carl-Ulrik, Ålund, Aleksandra \& Kings, Lisa (2014) "Reading the Stockholm riots - a moment for social justice?", Race \& Class, 55, 3, s. I-2I.

DoI: https://doi.org/I0.II77/030639681350919I

Schierup, Carl-Ulrik \& Ålund, Aleksandra (20II) "The end of Swedish exceptionalism? Citizenship, neoliberalism and the politics of exclusion”, Race \& Class, 53, I, s. 45-64. DoI: https://doi.org/Io.II77/03063968II406780

Sernhede, Ove (2002) Alienation is my nation. Hiphop och unga mäns utanförskap i det nya Sverige. Stockholm: Ordfront.

Sernhede, Ove \& Söderman, Johan (2013) "Kur mot kravaller", Sydsvenskan 24 maj 2013. URL: https://www.sydsvenskan.se/20I3-05-24/kur-mot-kravaller (3 september 20I7)

Socialstyrelsen (2010) Social rapport 20I0. Stockholm: Socialstyrelsen.

SvD (2008) "Två män anhållna för knivmord", Svenska Dagbladet I9 oktober 2008, s. II. Svenska Bostäder (2018) Järvalyftet.

URL: https://www.svenskabostader.se/var-historia/artiklar/jarvalyftet/ (23 mars 2018)

Tahvilzadeh, Nazem (20I3) "Förortsrörelsen: antirasistisk klasskamp som platskamp", Mana 3 februari 2013.

URL: http://tidskriftenmana.se/forortsrorelsen-antirasistisk-klasskamp-somplatskamp (3 september 20I7)

Thomson, Rachel m.fl. (2004) "Inventing adulthoods: a biographical approach to understanding youth citizenship", The Sociological Review, 52, 2, s. 218-239.

DoI: https://doi.org/IO.IIII/j.I467-954X.2004.00466.x 
Wacquant, Loïc (2008) Urban outcasts. A comparative sociology of advanced marginality. Cambridge: Polity Press.

Yin, Robert K. (2003) Case study research. Design and methods. Thousand Oaks: Sage.

Ålund, Aleksandra (1997) Multikultiungdom. Kön, etnicitet, identitet. Lund: Studentlitteratur.

Ålund, Aleksandra (20I2) "Alterity", i Ritzer, George (red.) The Wiley-Blackwell Encyclopedia of Globalization. Chichester: Blackwell Publishing.

Ålund, Aleksandra (2014) "Politics of belonging. A narrative on activism in Sweden", NORA, 22, 4, s. 330-337.

DOI: https://doi.org/I0.1080/08038740.2014.965199

\section{Inspelat material}

Erica, intervju den 22 september $2016,4 \mathrm{I}$ minuter.

Jasmine, intevju den 18 februari 2015, I timme 32 minuter.

Videoinspelning, I maj 20I2. Cirka 6 timmars videodokumentation av Megafonmedlemmars resa till Göteborg den I maj 2012. 


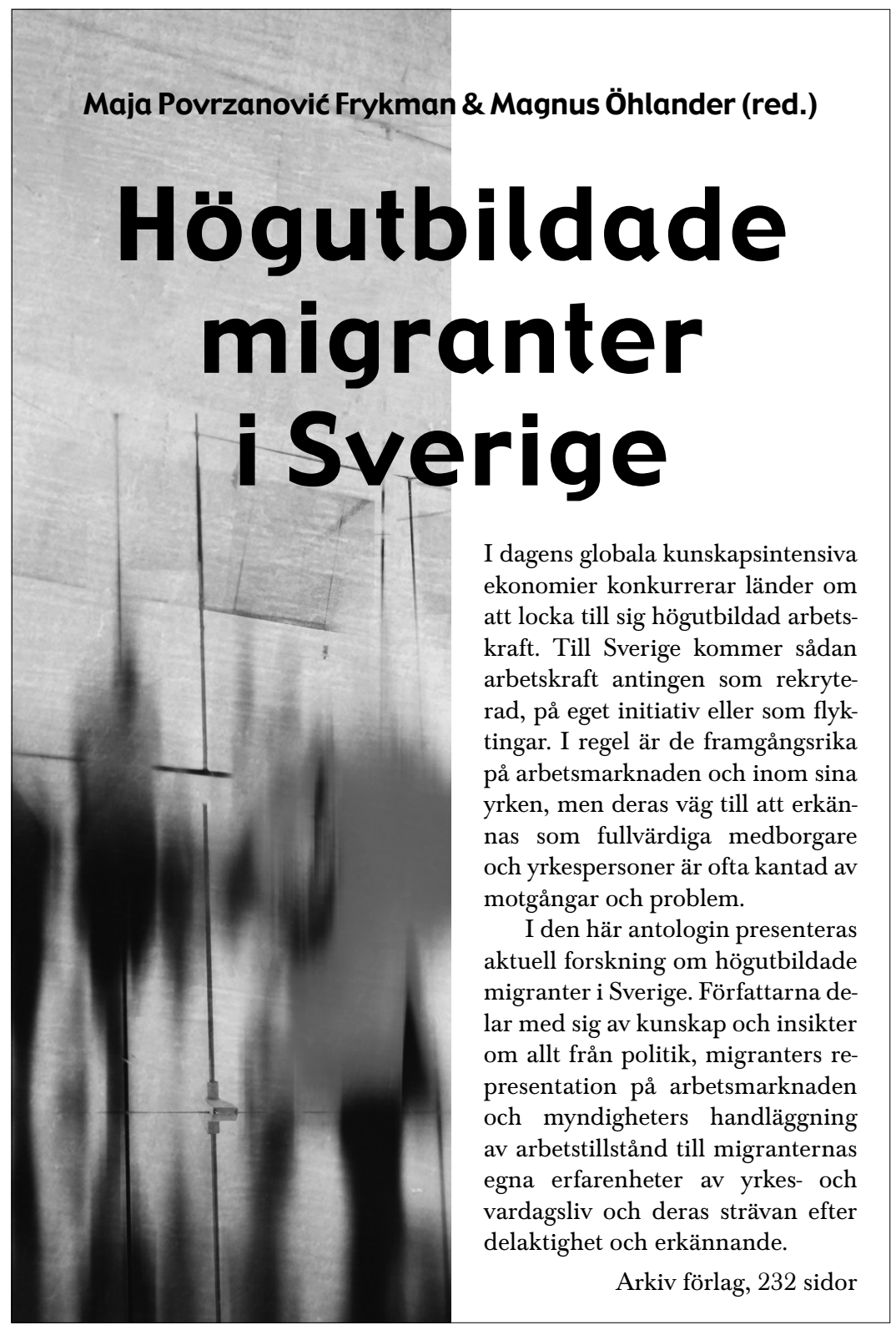

\section{»Läs mer om boken på www.arkiv.nu«}




\section{Moderna klassiker}

\section{Michel Foucault \\ Övervakning och straff}

\section{Arkiv förlag}

Varför intar fängelset en så dominerande plats i dagens straffsystem? Den frågan står i centrum för Michel Foucaults Övervakning och straff (Surveillir et punir), den kanske mest inflytelserika i hans långa rad av civilisationskritiska undersökningar. I ett språk som vibrerar av patos och inlevelse med de förtryckta och plågade illustrerar Foucault sina teser med skakande inblickar i straffets och disciplineringens historia. Denna klassiker finns sedan 2017 i en femte översedd och ombruten svensk upplaga som för första gången innehåller illustrationerna ur den franska originalutgåvan.

Översättning C G Bjurström, 422 sidor

»Läs mer om boken på www.arkiv.nu« 